\title{
Occurrence of lung cancer in workers producing chromium pigments
}

\author{
S LANGÅRD ${ }^{1}$ AND T VIGANDER $^{2}$ \\ From the Department of Occupational Medicine, ${ }^{1}$ Telemark Sentralsjukehus, 3900 Porsgrunn, and the \\ Department of Pulmonary Diseases, ${ }^{2}$ Bergen University, 5016 Haukeland Sykehus, Norway
}

\begin{abstract}
The results of a follow-up study on the incidence of lung cancer in 133 workers producing zinc chromate pigments are presented. By the end of 1972 three cases of lung cancer had occurred in a sub-cohort of 24 workers who had been employed for over three years. The same group of workers has now been followed up to December 1980 and three further cases of lung cancer were found. The observed/expected ratio was 44 in this group, virtually the same as at the end of 1972. Five of the six patients smoked. Only one had been exposed to chromates other than zinc chromates.
\end{abstract}

For 50 years chromates have been known to be potent inducers of cancer in exposed workers, ${ }^{1}$ while about 90 years ago one case of adenocarcinoma of the nose was reported by Newman ${ }^{2}$ in a worker who had previously been exposed to chrome pigments. Gross and $\mathrm{Kölsch}^{3}$ reported eight cases of bronchial cancer in chromium pigment workers, indicating that chromium pigments were carcinogenic in man. Until 1975 no epidemiological studies had been carried out on the suggested association between exposure to chromium pigment and lung cancer. A study reported in that year ${ }^{4}$ was initiated by the occurrence of bronchial carcinoma in a 41-year-old man in the city of Bergen in 1972 who appeared to have worked in a chromium pigment producing plant. ${ }^{5}$ The present study is a follow-up of the study presented in 1975.

In the previous investigation the study population was followed up from 1948, when chromium pigment production was started, to December 1972. Three cases of lung cancer were observed in those 24 of the total number of 133 workers who had by the end of 1972 worked in the plant for over three years. Three years later the same population was followed up. No new cases of lung cancer were observed, but there was a slight excess of cancer in the gastrointestinal tract in the same 24 workers. ${ }^{6}$

The initial study has been criticised ${ }^{78}$ partly because of the small study population and the small number of observed cases of cancer. There is no doubt that this criticism would have been valid if firm conclusions had been drawn from that small

Received 30 November 1981

Accepted 27 January 1982 study but no such conclusions were suggested in the study. Several studies, however, have been carried out since 1975 in workers producing chromium pigments $^{9}{ }^{10}$ (unpublished report of the Equitable Environmental Health Inc for the Dry Color Manufacturers' Association, USA, 1976) and also in users of chromium pigment-containing paints. ${ }^{112}$ Although the excess of cancer found in these studies was smaller than in our study ${ }^{4}$ they have all shown an excess of lung cancer in the workers.

These studies have also raised a new question: whether all classes of chromium pigments are capable of inducing cancer or if one of the pigments should be considered a more potent carcinogen than the others.' Animal experiments have indicated that lead chromate, in addition to zinc chromate, should be considered carcinogenic. ${ }^{1314}$

Cancer in the respiratory organs has been in focus in most studies with relation to exposure to chromates. ${ }^{15}$ The prime purpose of the present study was to reconsider the incidence of lung cancer in the population studied previously.

The production process in the plant has been altered considerably since the initial study was carried out. No lead chromate has been produced since 1956. The dust concentration has been reduced since 1973, partly because those production units with the poorest hygienic standards were closed in 1974 and 1980 respectively, and only the most satisfactory plant (the unit called plant $\mathrm{C}$ ) has remained in production. The level of zinc chromate dust in this plant has been monitored at regular intervals, and few measurements have exceeded $50 \mu \mathrm{g} \mathrm{Cr} / \mathrm{m}^{3}$. Most of the routine measurements during the period 
1975-80 show dust concentrations with $\mathrm{Cr}$ concentrations between 10 and $30 \mu \mathrm{g} \mathrm{Cr} / \mathrm{m}^{3}$.

\section{Methods}

To make the present follow-up study comparable with the previous study ${ }^{4}$ the same method has been applied for determining the expected and observed number of cases of cancer. The same list of all 133 male workers who had been employed between 1948 and December 1972 was used. The list was provided by the company in 1973 . Several workers started work after 1973. Assuming a development time (latent period) of 10 to 15 years for workers exposed to chromium pigment to develop cancer, none of these recently employed workers has yet had the chance to develop cancer induced by exposure to chromium pigments. As the level of exposure has also been considerably reduced since 1972 the recently employed workers should also be excluded for this reason.

Twenty-four of the 133 workers had been employed in pigment production for more than three years before January 1973.

The expected chance (risk) of developing cancer in the respiratory organs in the members of this small sub-cohort was calculated by using the ageadjusted incidence rates for lung cancer in the whole Norwegian male population for the period 1955-76, as presented by the Norwegian Cancer Registry. ${ }^{16} 17$ The chance of developing cancer was calculated from the beginning of the fourth year after first day of employment to the end of the year of death, or to the end of the year bronchial carcinoma was diagnosed, whichever was the earliest. Similarly, when using five years' employment as the requirement for admission to the study population, the chance of developing lung cancer was calculated from the beginning of the sixth year of employment. Since the data from the Cancer Registry do not include the cancer incidence figures for the years 1951-4, the incidence figures for 1955 were used for these years. The cohort was observed to the end of 1980 . Since the incidence figures have not yet been extended beyond $1976,{ }^{17}$ the mean incidence figures for the years 1974-6 were used for the period 1977-80.

As all new cases of cancer in Norway are reported and stored on magnetic tapes in the cancer registry, the registry was able to provide all cases of cancer that have occurred in the cohort from 1953 to 1980 , when linking the names in the cohort with the records in the cancer registry.

\section{Results}

By the end of 1980 the following cancers had occur- red among the 133 workers-lung (7), pancreas (1), stomach (1), large intestine (2), prostate (1), and nasal cavity (1). Four new cases of lung cancer had occurred since the initial study was carried out. Apart from these cases, one new case of cancer at other sites had developed since the end of $1975 .^{\circ}$ Three of the four new cases of lung cancer were recruited from the sub-cohort of 24 workers who had been employed for more than three years before 1973 (table 1).

The expected number of cases of lung cancer in this sub-cohort, based on the national figures, was calculated to be 0.135 , while the observed number of cases was 6 . This gives an $\mathrm{O} / \mathrm{E}$ ratio of 44 (table 1). The total number of man-years-at-risk in this sub-cohort was 391 .

When re-evaluating the list of workers it appeared that four workers had worked for over five years before 1972 in addition to the 14 indicated in the previous study. ${ }^{4}$ There were still only 18 included in this group. The expected figure for lung cancer was $0 \cdot 10$. Twelve of these 18 are still alive. One (case 6) has lung cancer, and one died of other causes in 1973 aged 68.

One case of cancer of the rectum was diagnosed in 1980 in a man born in 1910 who had been employed by the company for nine months in 1957 .

Details of the six cases of lung cancer in the subgroup of 24 workers are summarised in table 2 .

Table 1 Exposure characteristics of the cohort

\begin{tabular}{llll}
\hline & No of workers & \multicolumn{2}{l}{ No of lung cancers } \\
\cline { 3 - 4 } & & 0 & $E$ \\
\hline $\begin{array}{l}\text { Total } \\
>3 \text { years' }\end{array}$ & 133 & 7 & \\
$\begin{array}{l}\text { exposure } \\
>5 \text { years' }\end{array}$ & 24 & 6 & $0 \cdot 135^{*}$ \\
exposure & 18 & 6 & 0.10 \\
\hline
\end{tabular}

${ }^{*} \mathrm{E}=\mathbf{0 . 0 8}$ when using local reference population. 0.09 when correcting for 10 years' latent period.

\section{CASE REPORTS OF BRONCHIAL CARCINOMA}

Case $4^{*}$-Man born 1907 . He was employed by the company from September 1954 until he retired in 1974. From 1920 to 1954 he had been doing farmwork in the summer season and had been a fisherman during the winter season. During the 20 years that he was employed by the company he had been at plant $A$. Sack filling was the most dusty work in this plant. He had been exposed to no chromates other than zinc chromate dust. He had smoked about 10 cigarettes a day from about the age of 16 until 1971. A highly differentiated epithelial carcinoma in the left main bronchus was diagnosed in

${ }^{*}$ Cases 1-3 are reported in the previous publication. 
Table 2 Details on the six cases of lung cancer in 24 zinc chromate workers

\begin{tabular}{lllll}
\hline Case No & $\begin{array}{l}\text { Age when cancer } \\
\text { diagnosed }\end{array}$ & Work period & Year of diagnosis & Histological diagnosis \\
\hline 1 & 59 & $1949-54$ & 1968 & Anaplastic small cell carcinoma \\
2 & 51 & $1954-61$ & 1963 & Oat-cell carcinoma \\
3 & 41 & $1956-73$ & 1972 & Highly differentiated epithelial carcinoma \\
4 & 71 & $1954-74$ & 1978 & Highly differentiated epithelial carcinoma \\
5 & 49 & $1961-69$ & 1979 & Highly differentiated epithelial carcinoma \\
6 & 61 & $1954-80$ & 1980 & Adenocarcinoma \\
\hline
\end{tabular}

April 1978. He died in July 1979. At a medical examination in 1973 (by SL) a perforation of his nasal septum was found, of which a photograph has been presented elsewhere. ${ }^{18}$

Case 5-Man born November 1930. Employed by the company from October 1961 to January 1969 , when he had to stop working due to asthma which he had acquired during his employment as a sack filler at plant A. From 1944 to 1956 he was employed mainly in the silver trade, doing different types of work. From 1956 to 1961 he worked at a stamping-machine in an engine-producing factory. This worker had also been exposed only to zinc chromate dust at the study plant. He had smoked five to 10 cigarettes a day from about 1948 until a highly differentiated epithelial carcinoma in the left upper lobe was diagnosed in January 1979. He died in July 1979.

Case 6-Man born March 1918. Employed by the company since May 1954, the first 12 years at plant A, from 1966 to 1973 at plant B, and the last six to seven years at plant $\mathrm{C}$. He was a trusted worker doing all types of production work, the last years as foreman. He was engaged in zinc chromate production only, except for sporadic contact with calcium chromate. From 1933 until 1954 he had been a construction worker, and exposure to asbestos during this period cannot be excluded. He had been a pipe smoker from 1945 until he became ill in 1980, smoking 75-100 g of tobacco a week. Since 1973 this worker had been included in the health screening programme of the company. In March 1980 a $2.5 \mathrm{~cm}$ diameter round shadow was seen adjacent to the right upper bronchial branch. Biopsy of the tumour was not successful, but a biopsy specimen from the enlarged liver indicated the presence of a poorly differentiated adenocarcinoma. Since no other origin of the tumour could be found, it was assumed that the tumour originated from the lung. The patient has not been operated on and was still alive in August 1981.

\section{Discussion}

The results presented in the present follow-up study confirm the findings in the original investigation, which indicated an association between exposure to zinc chromate and the development of bronchial cancer. The present results strengthen the findings in the initial study and indicate that the cohort method can be used when studying the incidence of cancer even on small populations, provided the chance of developing cancer is high. Discrimination between the high and low risk groups within the population at risk is also necessary when using this method on small populations at risk.

Except for one case, all the new cases of lung cancer had developed within the sub-population that was considered to be at highest risk in 1973. Of the seven of the group of 18 who were ill, six had lung cancer; the remaining 11 are healthy.

The $O / E$ ratio for lung cancer has remained virtually constant since 1972 . In the present study the chance of lung cancer developing in those workers who have started work since 1972 has not been included in the calculation of expected risk. Had that been done, the expected figures would have been slightly higher. The assumed latent period for developing cancer has been included in the calculation of expected risk. When the latent period was assumed to be 10 years, and this latent period was excluded from the calculation of the expected figure, this figure was much lower (table 1).

The regional incidence of lung cancer was also used as a reference entity, this being lower than the incidence for the whole country ${ }^{19}$ (table 1).

The mean age at the time of diagnosis was 55.5 years in the six cases of lung cancer in the subpopulation. This is 8-10 years lower than in the general male population. ${ }^{15} 16$ Except for case $1,{ }^{4}$ all workers who have developed cancer have been exposed to zinc chromates and only sporadically to other chromates. Therefore the results presented here may serve only as documentation for considering the carcinogenicity of zinc chromate.

Five of the six patients with cancer are known to be smokers or ex-smokers. Since the present findings are very extreme, however, smoking should not be considered as an important confounder. ${ }^{20}$ Also, the present figures are too small in number to draw conclusions on possible interaction between smoking and chromium pigments. 
We thank the Cancer Registry of Norway for its co-operation and for valuable discussion with $\mathrm{Mr} \mathrm{Aa}$ Andersen. We thank Mrs U Danielsen for preparing the manuscript and Mrs P A Flor for linguistic help.

\section{References}

1 Lehmann KB. Ist Grund zu einer besonderen Beunruhigung wegen des Auftretens von Lungenkrebs bei Chromatarbeitern vorhanden? Zentralblatt für Gewerbehygiene 1932;19: 168-70.

${ }^{2}$ Newman D. A case of adeno-carcinoma of the left inferior turbinated body, and perforation of the nasal septum, in the person of a worker in chrome pigments. Glasgow Medical Journal 1890;33:469-70.

${ }^{3}$ Gross E, Kölsch F. Über den Lungenkrebs in der Chromfarbenindustrie. Archiv für Gewerbepathologie und Gewerbehygiene 1943;12:164-70.

4 Langård S, Norseth T. A cohort study of bronchial carcinomas in workers producing chromate pigments. $\mathrm{Br} J$ Ind Med 1975;32:62-5.

${ }^{5}$ Langård S, Kommedal TM. Bronchialkarsinom hos en ung man eksponert for kromater. Tidsskr Nor Laegeforen 1975;95:819-920.

- Langård S, Norseth T. Cancer in the gastrointestinal tract in chromate pigment workers. Arh Hig Rada Toksikol 1979;30,suppl:301-4.

${ }^{7}$ Kreyberg L. Lungekreft for arbeidere i kromindustrien. Tidsskr Nor Laegeforen 1976;96:50-1.

${ }^{8}$ Stokinger HE. The metals: 9 Chromium. In: Clayton GD,
Clayton FE, eds. Patty's industrial hygiene and toxicology. 3rd rev ed. Vol 2A. Toxicology. New York: John Wiley and Sons, 1981;1589-1605.

9 Davies JM. Lung cancer mortality of workers in chromate pigment manufacture: an epidemiological survey. Journal of the Oil and Colour Chemists Association 1979;62:157-63.

${ }^{10}$ Frentzel-Beyme R, Claude J. Lung cancer mortality in workers employed in chromate pigment factories. A multicentric Central European epidemiologic study. Am J Epidemiol 1980;112:423.

" Chiazze L, Ference LD, Wolf PH. Mortality among automobile assembly workers. I Spray painters. JOM 1980;22:520-6.

12 Dalager NA, Mason TJ, Fraumeni JF, Hoover R, Payne WW. Cancer mortality among workers exposed to zinc chromate paints. JOM 1980;22:25-9.

${ }^{13}$ Maltoni C. Occupational carcinogenesis. Excerpta Medicus International Congress Series 1974;322:19-26.

14 Furst A, Schlauder M, Sasmore DP. Tumorigenic activity of lead chromate. Cancer Res 1976;36:1779-83.

15 Enterline PE. Respiratory cancer among chromate workers. JOM 1974;16:523-6.

${ }^{10}$ Cancer Registry of Norway. Trends in cancer incidence in Norway 1955-1967. Oslo: Universitetsforlaget, 1972.

17 Cancer Registry of Norway. Incidence of cancer in Norway 1972-1976. Oslo: Norwegian Cancer Society, 1978.

${ }^{18}$ Langård S. Chromium. In: Waldron HA, ed. Metals in the environment. London: Academic Press, 1980:111-33.

19 Cancer Registry of Norway. Geographical variations in cancer incidence in Norway 1966-1975. Oslo: Norwegian Cancer Registry, 1978.

${ }^{20}$ Axelson O. Aspects on confounding in occupational health epidemiology. Scand J Work Environ Health 1978;4:85-9. 